\title{
Computational Science and Technology Applied to Biomedical Engineering
}

\section{1.はじめに}

\section{1 ポストゲノムと生命体システムの理解}

2003年, ワトソン・クリックのDNAの構造決定の論文発 表からちょうど50年が経過して, あらためて 20 世紀後半, とくにその最後の10年ほどの期間から現在にいたる生物学 の驚異的な進歩が振り返られている。マスコミを賑わした のはもちろんこの長足の進歩の画期をなしたヒトゲノム計 画を中心とする分子生物学の業績であった. 周知のように ゲノムの解読それ自身は塩基配列という暗号をいわば記述 したに過ぎず，次にはその意味を知るという本質的な作業 が待っている。ゲノムの解読は確かに偉大な業績であり, また，当初の予定が加速度的に繰り上げられて完成したこ とは記憶に新しいけれども, 今後の研究はゲノム解読の末 期がそうであったような，注入する人的・物的資源が結果 を制するというものではないと予想される。ゲノム解読以 後にますます明らかになっているのは，生物の信じがたい までの複雑性と多様性であり，分子生物学の成果を直接的 に現実に応用することの困難である。

上述した分子生物学の成果の応用の鍵は, DNA分子がも たらす情報を現実の物質的なシステムへと紡ぎ出す，分子 レベルから生体全体の巨視的レベルにまで，階層的に構成 される物理的抢よび化学的な細胞内外の環境の理解と制御 であることは疑いのないところである。それは，練胞とい うものが織りなす生命現象が自己と外界との相互作用の場 を通じてその形態・構造と機能を発現するということであ り，当然のことながら，無生物と他生物からなる環境が生 命の機能を制しているという事情はゲノム計画の完了以後 もまったく変わらない。

\section{2 バイオメカニクス}

われわれは, 生命体のシステムを機械工学的に解明し, 制御するための研究として, バイオメカニクス研究を進め てきた。ここで，機械工学的ということは，私見では，(広 義の）力学に基づいて現象を整理し, 力学環境の制御によ って, 生命現象への介入を行うという立場である。このよ うな研究は, ゲノムが話題になるはるか以前から生命体,

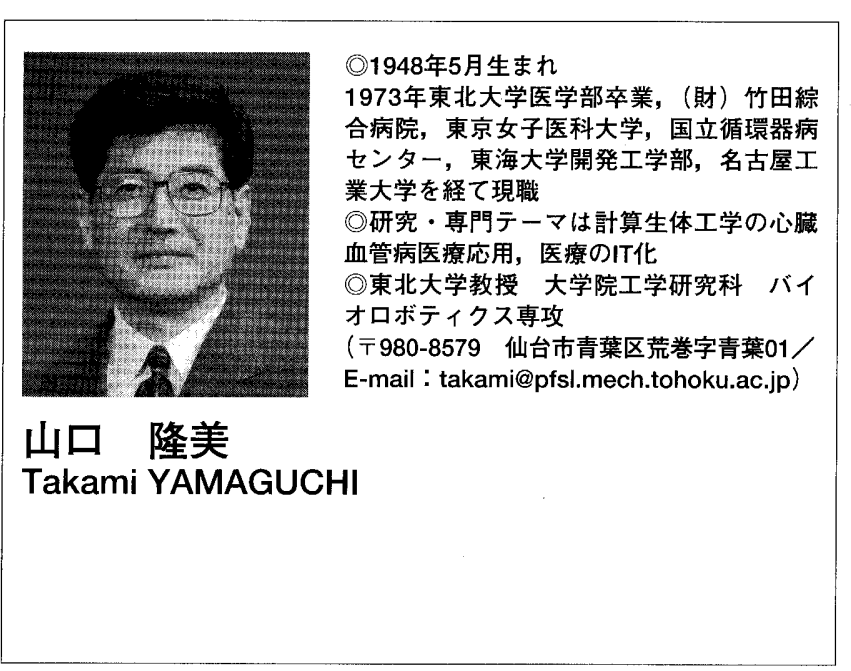

とくに，われわれ大型哺乳類の体制と機能をめぐる種々の 研究として発展してきた。近年では, 関連する周辺技術の 進歩，とりわけ，計算機技術の爆発的な進歩と画像技術の 進歩によってあらたな段階に達しつつあると考えられる。 本特集では，このような新しい学問，技術体系である計算 生体工学 (Computational Biomechanics) の最新の研究成果 が種々の側面から紹介される。本稿では，このような生命 現象の解明と, 得られた結果の応用の基礎となる医工連携 および医工学の課題について考えたい。

\section{2. 医工連携と医工学}

\section{1 医学と工学の対比}

あらためて言うまでもなく，工学が応用力学であるのと 同じような意味で医学は応用生物学であると言える。医学 が主として対象とするのはヒトであるが，ヒトが他の生物 (とくに動物) と生物学的に隔絶された性質をもっていると は考えられない. 大脳が発達していて，言語や思想をもつ こと，あるいは，多分その直接の結果として意味もなく同 種の他個体を殺したりすることを他の生物との差異として 強調する向きがあるかも知れないが，近年の類人猿の研究 からこれは否定される。このような特質あるいは性向は体 制組織の単純な生物から複雑な生物にかけて多かれ少なか れ連続的なものであるらしい。したがって，極論を言えば， 
医学が他の学問に比べて特殊であるとする根拠の最大のも のである, その目的, すなわち人命を預かり, それを尊重 し維持発展させることというのは，ヒトという動物種の工 ゴに過ぎないとも言える。言い換えれば，医学それ自身に 超越的かつ自己完結的な倫理があるわけではなく, それは, たかたか歴史的・集団心理的に決められた職業的世界観に 過ぎないと言える．突然，このようなことを取り上げるの は，現在，欧米および我が国で盛んに喧伝されている医工 連携を考える時に，どうしても，医と工とを相対化する必 要があると考えるからである，最近では使用頻度が減って いるが，医用工学という言葉には明らかに医学に奉仕する 工学という響きがあり，いまたに医の側にも工の側にもそ のように意識する人々は多い.

\section{2 医療工学}

医工学，あるいはわれわれが最近好んで使用する医療工 学という言葉に, われわれは医術ないし医学を工学によっ て改編するという考えを含意させている. 医学も工学も経 験科学の一分野であり, 経験の集積, 記述, 整理と, これ に対する対処法から成り立っている，ところで，試みに， 適当な臨床医学に関する教科書(1)をひもといてみれば一目 瞭然であるが，そこには極めて詳細に分類された現象と経 験が記述されているが，工学とは異なり，それを一貫して 説明する理論は, 少なくとも現在のところ存在していない ことに気付く. 近年臨床医学において, ある意味で金科玉 条のごとく強調される EBM (Evidence Based Medicine-証拠 に基づく医療）にしても，煎じ詰めれば，医療という生命 現象への介入のエピソディックな経験を, 統計学的な記述 に置き換えるということであり，そこに一貫した論理があ るわけではないことが多い（もちろん，それはそれで，“曰 く言い難い"経験と秘技伝授がすべてであった古い時代の医
療よりはるかにましではあることは言うまでもないが).

こういうわけで, 現実の医学・医療は, 方法論的に工学 の達成した水準に及んでいないという認識をもつことが医 工連携を論じるときに欠かせない。医学は壮大な現象論の 体系ではあるが，ヒトという統一された有機的システムを 全体的にとらえる方法論をもっていなかったのである。か くして, 医療工学は, 医用工学ではなく, 工学の手法で, 医学を再編するものでなければならない(2).

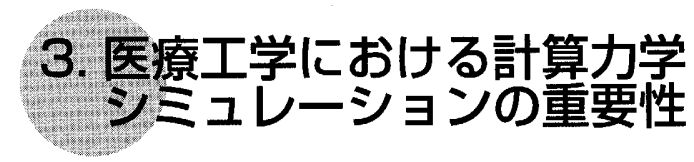

\section{1 計算生体力学の対象と課題}

上述した立場にたつなら, 医療を工学的に再編するため に必要なものは明らかである。それは，自然科学一般と同 様に，相互に鍛え上げる理論と実験であり，実験しがたい 現象に対する計算の三つの手法を適切に適用することであ る. 実験でも理論でもそうであるが，とくに，第三の手法 である計算を実施するときに，生命体の特殊性，すなわち， 生命体は，“生きている"ということとその階層性（図1）に 最大限の注意を払う必要がある。生きているということの 定義は困難であるが，さしあたりわれわれが興味をもつ生 体の力学現象の範囲では, 生命体システムが, 環境の変化 ないし働きかけに能動的に反応できるという能力と, 一部 その結果として, 自己を全システムとしても一部分であれ, 再生できることで特徴づけてよいであろう。しかも，この ような能力は，ゲノム=分子のレベルから，場合によっては 個体を越えて種のレベルまでも及ぶ.

計算生体力学シミュレーションは, 常に, 上述の生命体 の基本を踏まえて計画され実行されなければならない。た とえば, 何らかの物理的刺激が与えられた場合, 生体は,

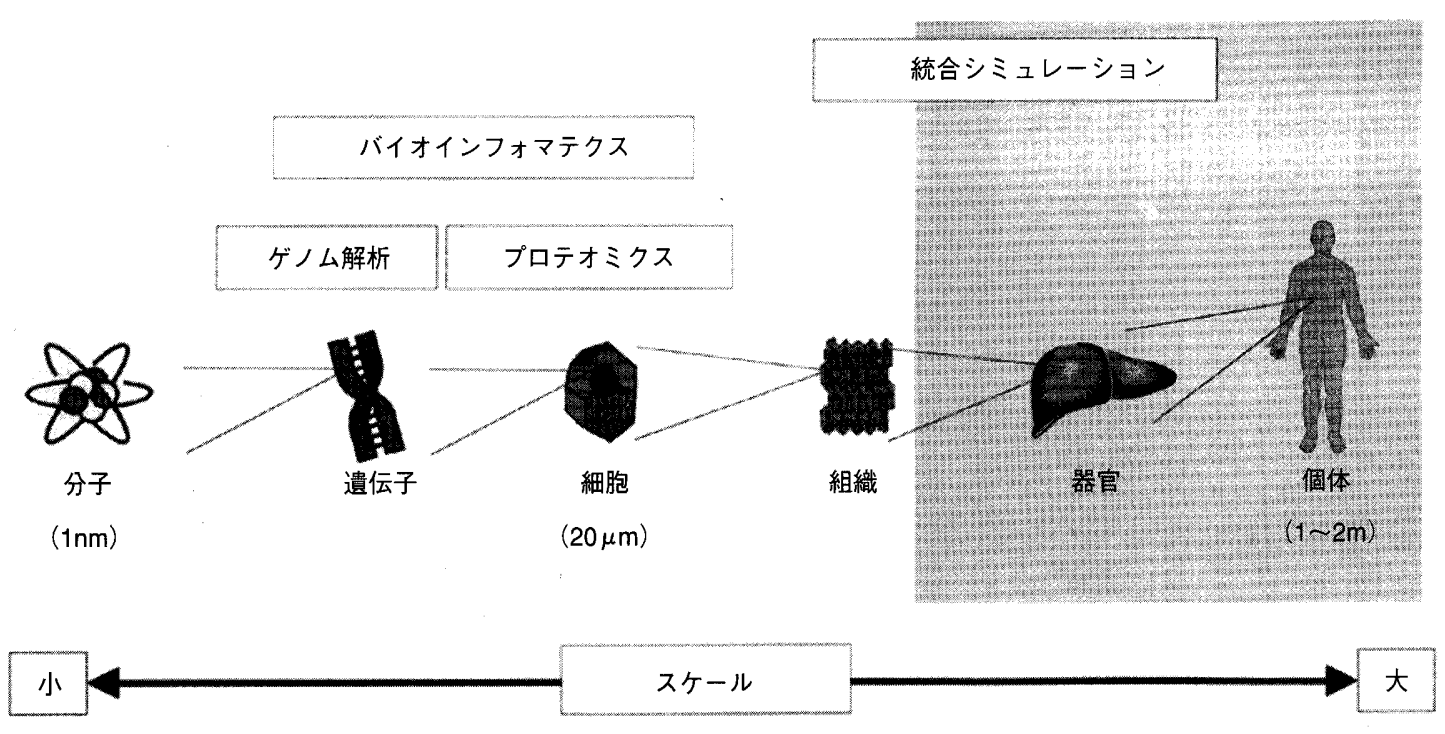

図 1 生体の階層性とモデル化の方針 
それが，ある程度の範讲内であれば，単純に材料疲労を起 こして破壊されたりはしない。このような環境下で, 細胞 と組織はその最大限の能力を動員して生理的あるいは病理 的に反応し，成功すれば適応し，耐えきれなければ死如。 この点は, 生体力学シミュレーション研究の計画と結果の 解釈において，強調してもしすぎない点であると考えられ る。この意味では, われわれがめざす生体力学シミュレー ションは，その主要な側面で，他の研究分野と同様に，複 雑現象を複雑なまま再現し, その複雑性を対象化して本質 を探るという目的を共有していると言える。

\section{2 統合シミュレーション}

一方で複雑を極める生命現象を解きほぐし，単純化した 側面を取り出すことで，その本質を理解するというシミュ レーションも不可欠である．生命現象は極めて多因子的で ある上に，階層的に構成されており，その因子の大部分が 未解明であるとともに階層間に複雑な相互作用がある。ま た，力学的にみても，生体の構成要素一たとえば，筋肉や 臓器一は, 非常に大規模であるが故に強い非線形性をもっ た変形が常態で，形状も非常に複雑である。このような条 件下での力学的解析は全く原理的に不可能というわけでは ないが，非常に困難であり，生命現象の本質に対する深い 洞察を基盤として，階層あるいは部分システムごとに単純 化することが必要かつ有効である対象も数多い. しかし， 注意したいのは，ここでも，鍵は生物学についての深い認 識であり，言葉の悪しき意味に㧍ける“機械的"な手段では 本質的理解には至らないことであろう。この意味で，図2に 示すような臓器・組織別のシミュレーションを統合するシ ミュレータの開発が必要であると考えられる。

\section{3 臨床診断・治療計画への応用}

さらに,シミュレーション技術の応用と確立が不可欠で
ある医学・生物学の領域として, 臨床医療における応用が 挙げられる，医療の成否を決定するのは，診断の精粗であ り，これに基づく治療の計画と結果の見積もりの精度であ る。診断の精粗を決めるのは，いかにして患者から必要な 情報を，しかも危害を与えずに獲得するかという技術であ り, これらの必要が, CT, MRIなどいくつかのノーベル賞 に輝いた医療画像工学技法を生み出した。これらの画像情 報のあるものは，それ自身，得られた情報に基づくシミュ レーションとしての性質を持っている。さらに，画像情報 は，たとえば三次元画像などに加工再構成されて診断の精 度の向上に多大の貢献をなしているが，さらに，一歩踏み 迄んでこのような画像を用いた各種力学シミュレーション のためのシステムが開発され実用に供されるようになって いる。このようなシステムは，今や，臨床現場の画像情報 機器システムの一部として，それとは分からない形で組み 込まれ提供されるようになっている。ここでの問題は，上 に述べた危険性, すなわち, 生物学抜きの力学解析とは反 対に, 力学解析に対する理解の欠如したシミュレーション 解析であり，計算の本質的困難を理解することなしに，あ るいは, 問題点を無邪気に無視した“医学的” 解釈で事足 れりとする傾向がとくに医学関係者が行う“シミュレーシ ヨン研究”には多いことも懸念される.

\section{4 医療技術教育における応用}

医工連携に㧍けるシミュレーションのもうひとつの重要 な応用分野は，臨床医学技術教育に拈けるその応用である. 医学に打ける技術の習得が, 最終的には複雑を極める現実 の疾病をもつ患者への医療を通じてしか实現できないこと は事実である。しかし，いやしくも“貴重な人命を”救い， 患者の苦痛を和らげることを究極目標とする医療が，少な くともその基本的かつ初歩的な技術の習得すら, 現実に病

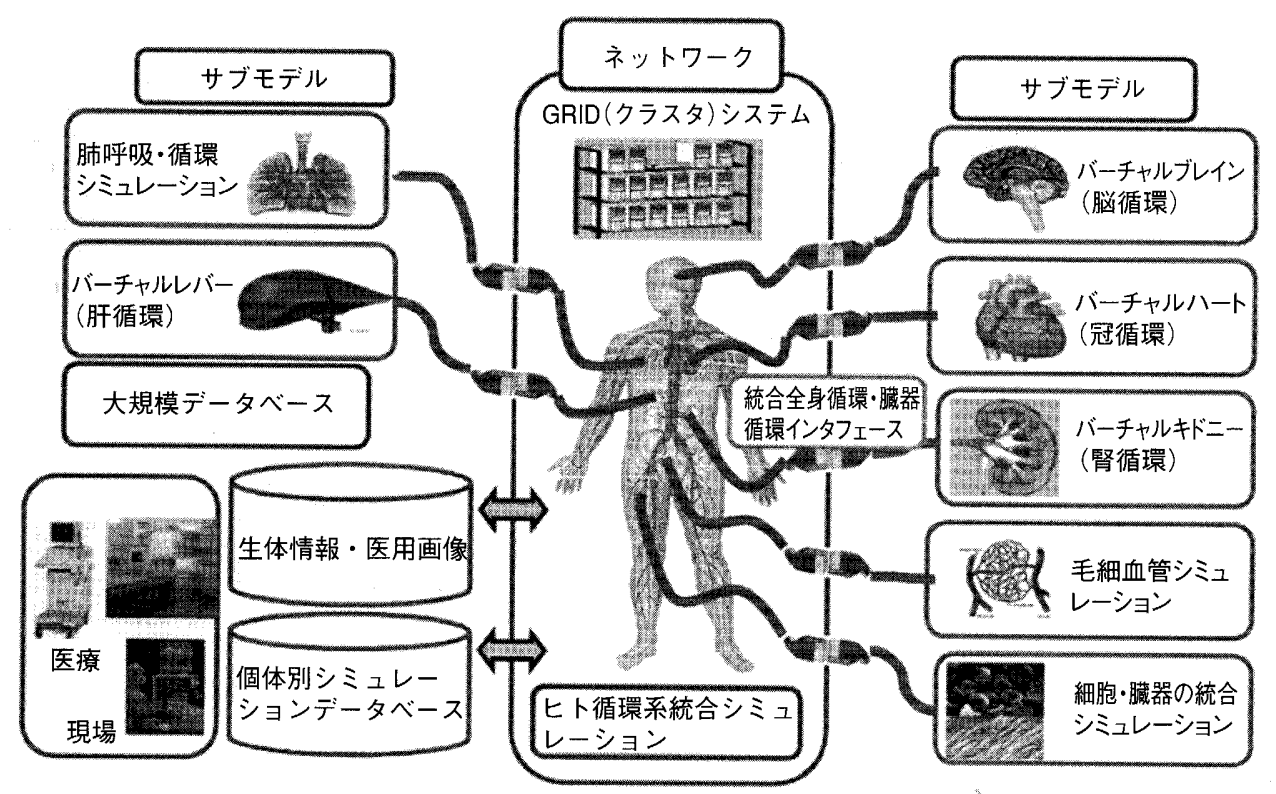

図 2 統合化ヒト循環系シミュレータ構想 
に苦しむ患者に対する医療行為の名を借りた実習で行うと いう事態は本来あってはならないことである. 今日, 飛行 機の操縦や，原子炉の運転の技術など，重大な人命に関す る事故を引き起こしかねない技能を習得する際に，まず， シミュレータによって，もっとも基本の技術の教育を受け ることは常識である。飛行機や原子炬よりはるかに複雑な システムであるヒトの体に何らかの（間違えれば患者を死 に至らしめる) 操作を加える医術の習得が, シミュレータ による入門教育を経ないということは，歴史的な経緯はと もかく，現代においては信じがたいことであると言わねば ならない.

\section{5 医療システムと安全確保のためのシミュレーション}

個々の医療技術者の技術水準の確保と維持はもちろん重 要であるが, 最近, とくに取り上げられることの多い医療 事故の防止と病院安全の確保においては, いたずらな精神 論を振り回すのではなく，実際に現場で医療を担う人材の 教育と啓発が必要であることが広く認識されるようになっ てきた.とくに, 医療組織内の系統的な情報流通がその鍵 であることが認識されるに至って, 病院・医療システムの 人的資源の質の向上と，このために重大な事故に至る些細 なトラブルをなくすための教育・再教育システムの確立が 説かれている。この場合も, 現実の患者を含む医療機関の 現場に扮いて基本的技術までを教育することは，患者にと っても，また，医療現場の質の向上という点からも改善が 必要である。この目的にも, 病院・医療機関の規模に応じ た医療システムシミュレーションを可能とする機器・モデ ルの開発が必要である。

\section{4. 今後の展望}

本稿のはじめにやや過激な表現で述べたように, 医工連 携といっても，医学には固有の問題点があり，工学にも当 然不足な点が多いから, 医者と工学者が一緒にいて, 適当 に依頼や話し合いをしたからといって，なにか新しいもの が出現するなどということはまずない。そもそも，相互に 話している事柄が何であるかを理解することが往々にして 絶望的に困難である。ナビエ・ストークスの方程式が究極 のところニュートンの第2法則であるということを, 式の上 で理解している医学者というのは, 極めてまれであろう。 他方, 12対の脳神経について，そのすべての主要な枝を走 行と機能をふくめて言える工学者というのも考えにくい. だかと言って, 相互の理解が不可能かと言えばそうでは ないし, 一方, 相互の理解なしに共同の作業を実現するこ とが可能かと言えば，これももちろんそうではない。いま から数10年まえに, 欧米や我が国の一角で, こういう相互 理解を試みた一群の人々がいて, 現在われわれがみるバイ オメカニクスという学問分野が構成されるに至った ${ }^{(3)}$. シ
ミュレーション研究においても現在同様の試みが, 少し形 を変えて進行しつつある。すなわち，医工双方向の教育・ 再教育の試みである，迂遠のようであるが，この基礎なし には，医から工への働きかけは，永遠に，“業者”への注文 であり続けるであろうし，一方，工から医への反応も，“お 医者様”への盲目的な服従であり続けると思われる. 対等 で創造的な相互作用は，相互の理解から始まるのであり， とくに機械工学会誌においてこの文章が読まれることを考 慮に入れるなら, 工学技術者があえて, 医学生物学の概念 を学び，用語を駆使することを身につけることにあると思 われる。

われわれは, 東北大学において文部科学省 21 世紀COEプ ログラム「バイオナノテクノロジー基盤未来医工学」(4)によ って, 医工連携の教育研究を実施しているが，その基本的 理念は, 上述のようなものである. 本プログラムは, 終了 後に, 大学院医療工学研究科拉よびそのエクステンション としての社会人再教育プログラムなどに発展することが意 図されて抢り,この過程で, 上述したような医療工学の構 築を目指している.

\section{5. 謝辞}

本特集を企画するための母体となった，日本機械学会部 門横断分科会「イメージベース卜連成バイオメカニクス解 析とその応用に関する研究分科会」(5)に参加されて活発な研 究活動と議論を展開していただいたメンバーの諸氏にここ ろより感謝申し上げるとともに, 幹事として分科会の運営 にご尽力いただいた神戸大学安達泰治, 東京大学大島まり, 吉湯宏，鈴木克幸の4氏にはとくに謝意を表したい.また， このような分科会の設置をお認めいただき，援助を賜った 日本機械学会にも感謝申し上゙る.

（原稿受付 2004年2月5日）

\section{文 献}

(1) Braunwald, E. ほか, 福井次矢, 黒川 清 (監訳)，ハリソン内 科学, 原軎第15版, (2003), メディカル・サイエンス・インターナ ショナル.

(2) 東北大学医工連携バイオ人材育成委員会, 平成14年度経済産業 省「バイオ人材育成システム開発事業」医療工学の指導的人材の育 成プログラム報告書, (2004-1), アドバンスソフト(株).

http://www.advancesoft.jp/bio

( 3 ) Caro, C. G.・ほか, The Mechanics of the Circulation, (1978), Oxford University Press.

(4) 東北大学文部科学省21世紀COEプログラム「バイオナノテクノ ロジー基盤未来医工学」ホームページ

http://www.fmbe.coe.tohoku.ac.jp

（5）日本機械学会部門横断分科会「イメージベースト連成バイオメ カニクス解析とその応用に関する研究分科会」ホームページ http://young.iis.u-tokyo.ac.jp/image-bio/ 